\title{
Fort Keogh Livestock and Range Research Laboratory's Historic Role in the Settlement of the West and Present Contributions to Range Ecology and Livestock Research
}

\section{By Mark K. Petersen and Jennifer M. Muscha}

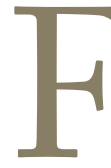
ort Keogh Livestock and Range Research Laboratory is a USDA-Agriculture Research Station located in Miles City, Montana. The mission of Fort Keogh is to develop ecologically and economically sustainable range animal production systems. The work involves studies in genetics, reproductive physiology, nutrition, and range ecology and management specifically related to grazing, drought, fire, weeds, and soil and water quality. Funding for research is provided by the USDA-Agricultural Research Service (USDA-ARS) in cooperation with the Montana Agricultural Experiment Station, which provides livestock and labor resources to the laboratory. It did not, however, start out that way.

\section{Fort Keogh Cantonment 1876}

After the Battle of the Little Big Horn and Custer massacre, General of the Army William Tecumseh Sherman ordered the establishment of Fort Keogh as an Army cavalry post on July 22, 1876. Fort Keogh was named after Captain Myles Keogh, an adjutant to General George Custer, who was killed in the Battle of the Little Big Horn on 25 June 1876.

Establishment and early development of Fort Keogh was under the direction of General Nelson A. Miles, for whom Miles City is named. A site was selected in a stand of cottonwoods just south of the confluence of the Tongue and Yellowstone Rivers. The rugged hills west of the location provided much needed protection from the winter winds. In large part, General Miles's success against the hostile Indians was due to the fort's location. Most crews and supplies were sent to Fort Keogh by steamboat up the Yellowstone River in the spring and summer with the "June rise" of the water, and later by rail when the Northern Pacific Railroad line was completed from Bismarck, North Dakota, to the fort in 1881.

By the end of 1877, numerous buildings were in various stages of completion. Six barracks built to house 11 companies were almost complete. Other buildings included a hospital, guard house, bakery, six cavalry and two quartermaster stables, three storehouses, granary, quartermaster's offices, adjutant's offices, commander's offices, ordnance store, engine house, blacksmith/wheelwright shops, library, and billiard hall. ${ }^{1}$ For several years Fort Keogh was one of the largest US Army posts, and the soldiers considered it one of the most livable posts in the west.

General Miles' main duty from 1877 to 1881 was to pursue the hostile forces under the leadership of Sitting Bull, Gall, Crazy Horse, and other Sioux and Cheyenne chiefs who remained in the area. After Sitting Bull surrendered at Fort Buford, North Dakota, on 19 July 1881, the Indian conflicts were mostly over. From 1881 to 1890, Fort Keogh's main role was to keep peace in the territory. The Battle of Wounded Knee on 29 December 1980, was the last Indian campaign for the Fort Keogh troops.

Many Indians taken prisoner during the first major battles in the winter of 1876-1877 were housed at Fort Keogh. Other Indians came to the fort and surrendered directly to General Miles. Three hundred Cheyenne surrendered 


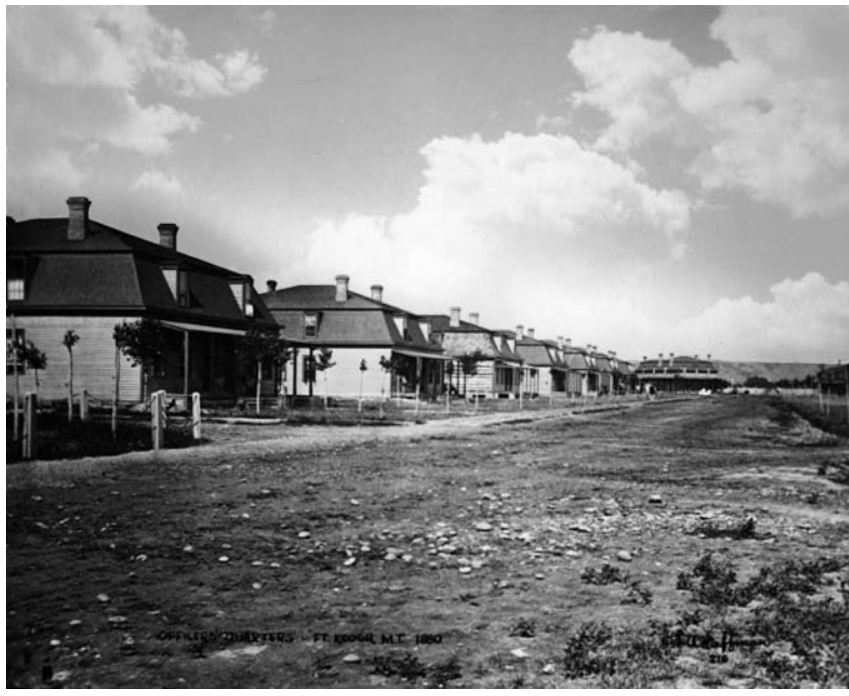

Officers' quarters, Fort Keogh, 1880. Photo by L. A. Huffman.

during the first few months of 1877. General Miles allowed the Indians a lot of freedom while at Fort Keogh, and he took on the responsibility of their care and education. After Chief Joseph and his Nez Perce followers were captured by General Miles, they were kept in camp across the Yellowstone from Fort Keogh during the winter of 1877-1878 and sent to the Indian Territory the next year. The Indian prisoner population at the fort was 407 in mid-1879 including Cheyenne, Sioux, and Bannocks. ${ }^{1}$ In late July 1879, about 300 lodges of Sioux surrendered at Fort Keogh. Colonel Miles, upon hearing of the unhappiness of the Cheyenne at the Pine Ridge Agency (in South Dakota), requested their transfer to Fort Keogh. Miles wanted to educate the Indians in his charge about agricultural practices. To ensure against hunger, he also issued ammunition to the Indians to hunt buffalo and other wild game. His fair methods in dealing with the Indian prisoners speeded the surrender of other hostile forces. Starvation conditions in Canada drove the Sioux to seek surrender at Fort Keogh starting in mid-1880. In April of that year, a group of about 100 Sioux surrendered at the post; the following month over 700 Sioux under Chief Rain-in-the-Face surrendered. Feeding the nearly 1,000 Indians became a major project for the Army. The Sioux continued to surrender in August, September, and October of 1880. This brought the population of prisoners to approximately 1,500. The number again increased on 31 October 1880, when Lieutenant Eli L. Huggins returned to Fort Keogh with Spotted Eagle's band of 600 Sioux. This brought the total Sioux population alone up to 1,482. Secretary of Interior Carl Schurz visited Fort Keogh in August of 1880 and decided to relocate the Sioux to the Standing Rock Agency of Dakota. ${ }^{1}$ Sioux Indians were loaded on board five steamers. It was a sad occasion for the Indians, and some soldiers and civilians were saddened by it as well. With this massive movement, the Indian population of Fort Keogh dropped to a few hundred Cheyenne.

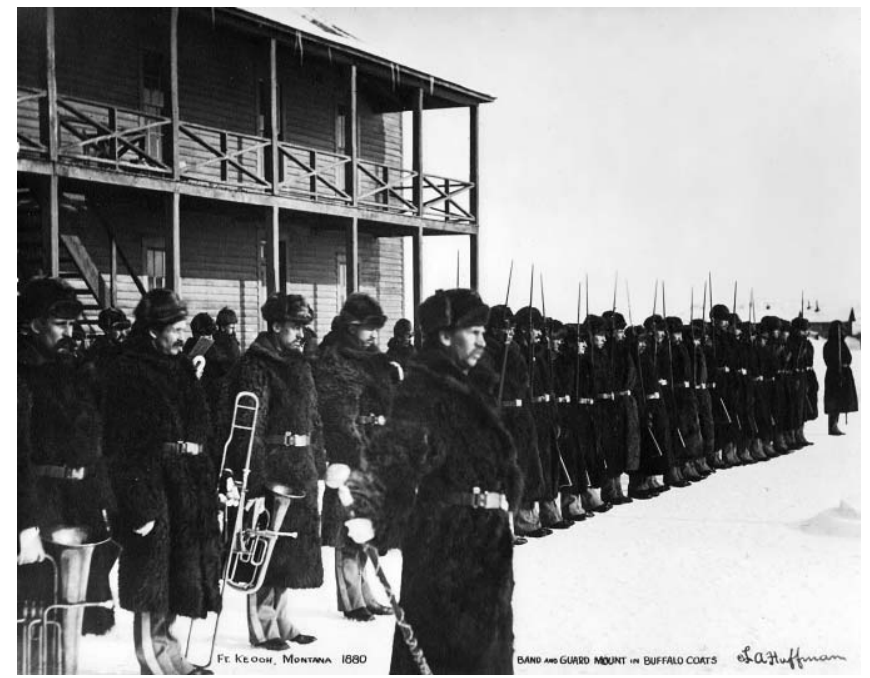

Band and guard mount in buffalo coats, Fort Keogh, 1880. Photo by L. A. Huffman.

General Miles succeeded in his mission. By the early 1880s most of the tribes had surrendered and were moved onto reservations. In 1907 all infantry troops were withdrawn, and in 1909 Fort Keogh became a Remount Station for the US Army. This Remount Station was very active in World War I. During this period, more horses were processed here than at any other Army post in the United States.

With the relocation of all Indians onto reservations and the invention of motorized vehicles, the Army no longer saw a need for soldiers at Fort Keogh. In 1922 the Army relinquished the land, and the Fort Keogh military withdrawal was completed on 2 February 1924. Onsite remains of the original fort include the parade ground, a wagon shed built in 1883, the flag pole erected in 1887, and seven other structures built before 1924 .

Additional information about the early days of Fort Keogh can be found at http://www.ars.usda.gov/Main/docs. htm?docid=6395.

\section{USDA Livestock and Range Research Station $1924^{2}$}

\section{Animal Research}

By an Act of Congress dated 15 April 1924 (PL90, 43 Stat. 99) jurisdiction of the Fort Keogh Military Reservation was transferred to the USDA for experiments in stock raising and growing of forage crops. The early experiment station was a widely diversified unit. There were approximately 1,200 Rambouillet ewes and lambs on breeding and feeding experiments and wool studies. All sheep were transferred to the US Sheep Experiment Station, Dubois, Idaho, in 1941. A Milking Shorthorn dairy herd was maintained on the laboratory. The animals were not used extensively for research purposes, and the herd was dispersed in the late 1930s. 
Many horses have also been used in experiments. A 1934 inventory showed 250 head on breeding, feeding, and reproduction studies involving purebred Belgian, Morgan, and Thoroughbred sires. Some of the early work to develop successful semen collection and artificial insemination techniques in horses was conducted at this laboratory. The Thoroughbred breeding herd was maintained until 1964.

Studies with Bronze turkeys started at the laboratory in 1929 and involved approximately 1,500 young turkeys and 350 breeding hens. Studies consisted of feeding, breeding, and rearing experiments, and the original crosses and early work led to development of the Beltsville White breed. This line of research was closed out in 1939, when the turkeys were shipped to Beltsville, Maryland.

Early swine research was directed toward production of Wiltshire Sides for the European pork market. The swine work is most famous for the development of the Montana No. 1 breed, a cross between the Danish Landrace and the Black Hampshire breed. Crosses were inbred, and through selection one of the first meat-type breeds was established. Federal funding for swine research at the laboratory was terminated in 1968, and swine work was directed to the Animal and Range Sciences Department at Montana State University. Work involving the Montana No. 1 and the Yorkshire breeds was terminated in 1971. The swine research was moved from Fort Keogh to Bozeman in 1986.

In 1924 with 188 registered Hereford, the cattle herd was started at Fort Keogh. Methods for genetic evaluation of beef cattle were pioneered at Fort Keogh in the 1930s. All beef performance testing programs now active in the United States and much of the rest of the world are built on this foundation. Today's producers continue to benefit from this work as they use estimated breeding values and expected progeny differences to select breeding stock that meet their needs. Some of the breed association equations

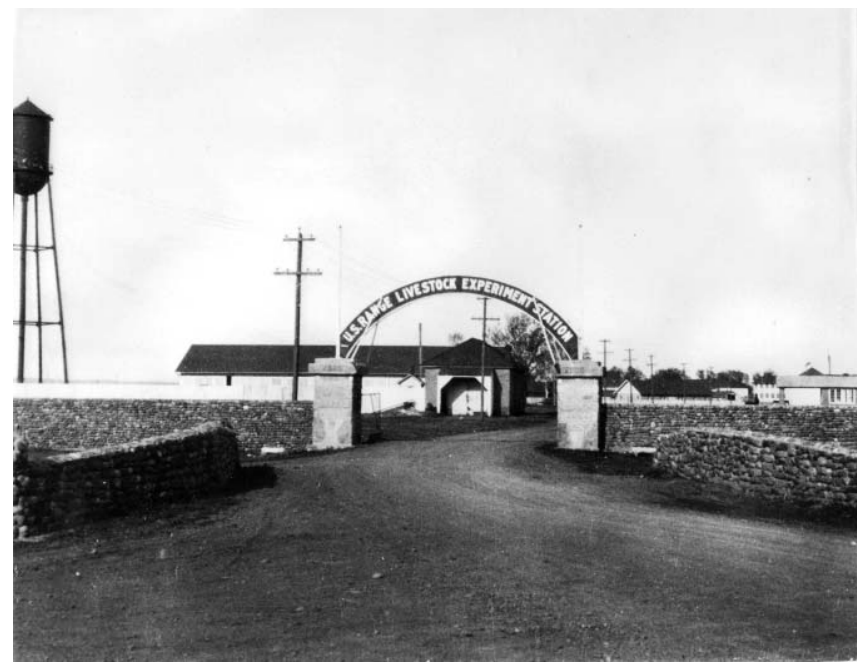

Archway over the entrance to Fort Keogh, 1926. Photographer unknown. for predicting these values have been developed at Fort Keogh (Mike MacNeil, Quantitative Geneticist, Fort Keogh, personal communication). Success of the Line 1 Hereford cattle 76-year-long single-trait-selection experiments demonstrates the commitment to high-impact, longterm research. Genetic material deciphered in the bovine genome project was supplied by Line 1 Hereford Dominette no. 01449.3 Neonatal mortality resulting from calving difficulty continues to be a major source of lost revenue for beef producers. Workers at Miles City first established the role of birth weight as the most important causative factor associated with calving difficulty.

Winters in the Northern Great Plains can be long and cold. These environmental factors add stress and compete for calories. On the other hand, summers can be dry and hot. Consequences of the physiological and metabolic strain of stress can be manifested in the reproductive efficiency of the cow herd. Current studies in this vein suggest mild in utero stress can positively influence adaptability and productive longevity. ${ }^{4}$ Delaying calving a couple of months from the traditional late winter period to late spring may increase the opportunities to graze and utilize supplement compared to feeding hay. ${ }^{5}$ Grazing time and forage intake may be reduced by extreme cold during a time when the energy requirements of the cow are increased. Nutrition studies conducted at Fort Keogh have demonstrated the importance of proper winter supplementation ${ }^{6}$ regimes for optimum rates of subsequent conception, calf survival, and cow and calf weight gains. ${ }^{7}$

\section{Range Research}

Research in range improvement and management was initiated at Fort Keogh by the US Forest Service in 1932. Early studies were designed to determine optimum stocking rates for cattle and sheep on Northern Great Plains rangelands. A 24-year study determined that a moderate stocking rate of 2.6 acres/animal unit month (30.5 acres/cow yearlong) was not detrimental to the vegetation, soils, or livestock. This recommendation was used by agencies and producers to determine appropriate stocking rates on Northern Great Plains rangeland. Use of this standard improved range health by increasing plant growth, reducing soil erosion, and increasing production of both domestic livestock and wildlife. Beginning in 1936, water spreading systems were developed by building diversion dams and contour dikes. These studies were among the first in the nation to demonstrate that water normally lost to runoff could be used effectively to increase growth of native and introduced grasses. Research on Fort Keogh has shown weather to be the most important variable controlling the amount of prickly pear in any given year. Many varieties of introduced perennial grass species have been tested at Fort Keogh. Russian wildrye and crested wheatgrass have proved to be the most productive and grazing tolerant for the Northern Great Plains region. 
Drought is an important consideration when planning grazing management. The penalty for not planning early during drought conditions has been shown experimentally to include rapid reduction of the available forage, reduced flexibility of management alternatives, and potential deterioration of the landscape. ${ }^{8}$ Along with drought, wildfires have shaped the landscape. Northern Great Plains native vegetation evolved under its influence and is resilient to its impact. Current studies are investigating the effects of light, moderate, and heaving grazing the first year after fire on native vegetation. Climate change research at Fort Keogh determined carbon sequestration in these grasslands is generally low and affected more by climatic conditions than grazing tactics. Another aspect of rangeland vigor is its susceptibility to invasion by weeds, of which annual bromes are especially intrusive. Annual bromes are cyclic in the Northern Great Plains and depend on the amount and distribution of moisture, temperature, and seedbank. ${ }^{9}$ Fort Keogh research has demonstrated the potential to severely affect the fertility of annual brome seeds with low-level herbicide treatment. ${ }^{10}$

More information on past and current research at Fort Keogh can be found at http://www.ars.usda.gov/Main/docs. htm?docid=3087.

\section{The Future of Fort Keogh}

Our future research objectives will be parallel to our ongoing efforts because we believe there is still much to be learned about how management can improve ecological, biological, and economic efficiencies in a rangeland agriculture (i.e., grazing) setting. Our approach to research will progress toward greater collaboration within Fort Keogh as well as off-location cooperation. We plan to promote off-location relationships through our university partnerships and graduate students facilitating a portion of their thesis work at Fort Keogh. We are presently participating in two large-group grant proposals from USDA's Agriculture and Food Research Initiative: a beef cow efficiency effort with scientists at five institutions, and a second focused on grassland disturbance with 30 cooperators involving over a half dozen institutions or agencies. Our goal is to leverage our resources with others to enhance our science and improve the economic efficiency of the cost of conducting research.

\section{Facilities, Management, and Personnel}

The size of the original Fort Keogh Military Reservation was 100 square miles or 64,000 acres. The Fort Keogh Livestock and Range Research Laboratory (LARRL) now occupies about 55,357 acres. In 1878 a large piece of land east of the Tongue River was released by the Army and is now the present site of the city of Miles City. Since that time, additional land has been released for the Miles City industrial sites, Custer County fairgrounds, the warm-water fish hatchery, and Spotted Eagle Recreation Area.
The cattle and farming operation at Fort Keogh LARRL serves to support the research work. Cattle numbers and crop production are driven by research needs within limits imposed by responsible stewardship of the resources. The farming operation is managed to provide quality feed for research livestock using proper conservation and agronomic practices. Currently, approximately 800 acres are irrigated cropland, 2,000 acres are seeded dryland pastures, and 49,000 acres are native grasslands. There are 169 pastures ranging in size from 13 to 3,000 acres. Fort Keogh has approximately 220 miles of roads and trails, 400 miles of fence, 103 water tanks, 55 reservoirs, 16 springs, 10 creeks, and 2 rivers. Depending on the year, the cattle numbers range in size from 1,200 to 1,550 mother cows. There are four cattle herds on the station: Line 1 Herefords, CGCs (a composite breed with a genetic makeup of $25 \%$ Charolais, 50\% Red Angus, and 25\% Tarentaise), and two Hereford-Angus crossbred herds.

Current staff of USDA-ARS personnel consists of nine scientists, 10 technicians, and six administrative staff. The Montana Agriculture Experiment Station employs 15 ranch/ farm workers, one professional, and one administrative staff. Two Montana State University Extension personnel are also located at Fort Keogh.

\section{References}

1. Warhank, J. J. 1984. Fort Keogh: Cutting edge of a culture. [thesis]. Long Beach, CA, USA: California State University. $133 \mathrm{p}$.

2. Bellows, R. A. 1981. The livestock and research station. 1981 Field Day: research in action. Miles City, MT, USA: USDA-ARS. 9 p.

3. Elsik, C. G., R. Gibbs, L. Skow, R. Tellam, G. Weinstock, K. Worley, S. M. Kappes, R. D. Green, L. J. Alexander, G. L. Bennett, J. A. Carroll, C. G. Chitko McKown, D. L. Hamernik, G. P. Harhay, J. W. Keele, G. Liu, M. D. MacNeil, L. K. Matukumalli, M. Rijnkels, A. J. Roberts, T. P. Smith, W. M. Snelling, R. T. Stone, R. C. Waterman, and S. N. White. 2009. The genome sequence of taurine cattle: a window to ruminant biology and evolution. Science 324:522-528.

4. Roberts, A. J., T. W. Geary, E. E. Grings, R. C. WaterMAN, AND M. D. MacNeil. 2009. Reproductive performance of heifers offered ad libitum or restricted access to feed for a $140-\mathrm{d}$ period after weaning. Journal of Animal Science 87: 3043-3052.

5. Grings, E. E., A. J. Roberts, T. W. Geary, and M. D. MACNeIL. 2008. Milk yield of primiparous beef cows from three calving systems and varied weaning ages. Journal of Animal Science 86:768-779.

6. Waterman, R. C., C. A. Lõest, W. D. Bryant, and M. K. Petersen. 2007. Supplemental methionine and urea for gestating beef cows consuming low quality forage diets. Journal of Animal Science 85:731-736.

7. Adams, D. C. 1989. Wintering beef cattle on rangeland. In: T. Goehring [ed.]. Proceedings of the XI Range Beef and Cow Symposium: a symposium on production; 5-7 December 1989; 
Rapid City, SD, USA. Brookings, SD, USA: South Dakota State University. p. 148-159.

8. Heitschmidt, R. K., and L. T. Vermeire. 2006. Can abundant summer precipitation counter losses in herbage production caused by spring drought? Rangeland Ecology \& Management 59:392-399.

9. Haferkamp, M. R., J. D. Volesky, M. M. Borman, R. K. Heitschmidt, and P. O. Currie. 1993. Effects of mechanical treatments and climatic factors on the productivity of Northern Great Plains rangelands. Journal of Range Management 46:346-350.
10. Rinella, M. J., M. R. Haferkamp, R. A. Masters, J. M. Muscha, S. E. Bellows, and L. T. Vermeire. 2010. Growth regulator herbicides prevent invasive annual grass seed production. Invasive Plant Science and Management 3:12-16.

Authors are Research Leader (Petersen) and Rangeland Scientist, jennifer.muscha@ars.usda.gov (Muscha), USDA Agricultural Research Service Fort Keogh Livestock and Range Research Laboratory, Miles City, SD 59301, USA. 